\title{
The Effect of Sustainability Reporting Disclosure and Its Impact on Companies' Financial Performance
}

\author{
Chairina and Enny Hardi \\ Faculty of Economics and Business, Lambung Mangkurat University, Indonesia
}

\begin{abstract}
The purpose of this research was to examine empirically the effect of sustainability reporting disclosure on companies' financial performance. Sustainability reporting is a report that measures, discloses and shows the responsibility of the company to internal and external parties as an accountability form of organization performance in order to gain continuous development purpose. Sustainability reporting becomes trend and need for companies to disclose economic, environmental, and social performance to stakeholders. Samples of40observations were derived from companies that consistently become Indonesia Sustainability Reporting Award (ISRA) nomination and listed in Indonesia Stock Exchange (BEI) during 2016-2017. Sustainability reporting measured by Global Reporting Initiative (GRI) continuous reporting guideline-G4 with 91 indicator items and financial performance measured by Return on Assets (ROA). The analysis method used was Multiple Linear Regression. The results of the research showed that Economic Dimension Disclosurein sustainability reporting has effect on financial performance. Whereas, Environmental Dimensionand Social Dimension have no effects. The condition indicates that sustainability reporting in short term has not been able to affect companies' financial performance.
\end{abstract}

Keywords: Sustainability reporting, Economic Dimension, Environmental Dimension, Social Dimension, GRIG4, ISRA

\section{INTRODUCTION}

The main goal of the company is not only to seek profits or gain, but also the company is expected to be able to provide benefits to all parties involved in it, i.e. consumers, employees, society and the environment in related to management and shareholders. Basically, companies must maintain good relationships with their stakeholders, especially in the availability of resources to carry out operational activities. This awareness drives the community to expect the information disclosure by companies that is not only limited to one aspect of performance or single bottom line, but also overall indicators, sustainability performance that is economic, social and

Correspondence: Chairina, Faculty of Economics and Business, Lambung Mangkurat University, Indonesia, chairina_adnan@yahoo.co.id environmental performance or triple bottom line (Ken, et.al, 2012).

Sustainability report is a report that measures, discloses and shows the responsibility of the company to internal and external parties as well as accountability efforts from organizational performance in achieving sustainable development goals. The goal of the sustainability report is to meet the living needs of the present generation without disrupting the ability of future generations to fulfill their lives by paying attention to environmental aspects and social aspects (Maria, 2014). Sustainability report can be a benchmark for the company has been carrying out the sustainable environmental development. Sustainability report is presented into two forms of reports both reported separately or in the Annual report. Annual report is a tool used by companies to communicate with external 
parties. Sustainability report activities can be said as part of good corporate governance, which is expected to improve the company's financial performance. Performance is often associated with the company's financial condition. Information on company performance, especially profitability, is needed to assess the economy in the future. Sustainability report researches continue to develop related to the sustainability report's impact on company performance (Tarigan \& Samuel, 2014; Nur Maharani, 2014; Safitri \& Fidiana 2015, Dewi \& Sudana 2015).

Since 2005, the Indonesian Institute of Management Accountants (IAMI) and Institute of Indonesia Chartered Accountants (IAI) Management Accountants Compartment in collaboration with the National Center for Sustainability Reporting (NCSR) awarded the sustainability reporting award for companies that well reported their sustainability performance in the social, environmental and economic fields. IAMI awards on reporting sustainability performance is very important to improve the performance itself. Reporting will trigger benchmarking, learning, setting and achieving targets and building accountability, transparency, and encouraging the involvement of all stakeholders.

This study focuses on the effect of continuous reporting disclosure on a company's financial performance. Financial performance is measured using profitability which is proxied by Return on Assets (ROA). Whereas for sustainability reports, economic, environmental and social performance use proxy index sustainability report (GRI-G4) with 91 disclosure items during 2016-2017 in publicly listed companies that are included in the ISRA (Indonesia Sustainability Reporting Index) nomination. The companies included in the ISRA nomination are expected to be able to build a positive image for the company so that people are increasingly interested and loyal to Journal of Wetlands Environmental Management Vol 7, No 1 (2019) 67 - 75 http://dx.doi.org/10.20527/jwem.v7.v1.188 the products sold. If product sales increase, it will have an impact on increasing company profits. The ISRA nominees are expected to be able to increase the company's positive image which will impact on increasing sales and profits.

Stakeholder Theory that explains the management, recommend attitudes, structures and implemented practices will shape the stakeholder management philosophy and related to stakeholders and information received. Companies must continue to strive to build and maintain good relationship with stakeholders. (Hill \& Jones, 1992; Donaldson \& Preston, 2005; Freeman \& McVea, 2001). This thought leads to the existence of a company or organization that is influenced by support from parties who have a relationship with the company. The company does not only operate for its own sake but also must be able to provide reciprocal benefits to its stakeholders. This theory is also in line with legitimacy theory. Legitimacy theory emphasizes that companies continue to strive to ensure that they operate within the framework and norms that exist in society or the environment in which the companies are located, where they strive to ensure that their activities are received by outsiders (Deegan, 2006).

One of the efforts to build good relations with stakeholders is to create business sustainability by using the triple bottom line concept. The Triple Bottom Line (TBL) is an Accounting framework that combines 3 dimensions, i.e. social, environmental and financial dimensions. The three dimensions in TBL are commonly called people, planet, and profit (Slaper\& Hall, 2011). TBL is the most important tool used to support sustainability goals. TBL is increasingly demanded by companies or profit organizations, non-profit, and government. Companies or organizations begin to adopt TBL in sustainability reports to 
evaluate performance. Evaluation of financial performance can be seen from the profitability ratio. Profitability is the company's ability to earn profit related to assets, the level of sales and certain stock capital. One way to measure profitability ratio is to use ROA (Return on Assets). ROA is a measurement of the returns produced by the company on its assets. This measurement is measured based on the way the organization finances its assets (Anthony, et. al, 2012; Hanafi, 2013).

Information contained in a continuous report on the economic dimension can help stakeholders to believe that competitive capital resources have a low level of risk. With the trust of investors and creditors, the funds owned by the company will increase, making it easier for companies to improve their financial performance. Information contained in economic performance is considered more transparent when compared to the financial performance of the company, because stakeholders consider economic performance to be higher in accuracy for predicting and analyzing lower risk information. This proves that economic performance in sustainability reports has an influence in increasing company profits. The management approach covers three economic aspects such as indirect economic impacts and market presence (Natalia \&Tarigan 2014). From the above arguments, the proposed hypothesis is:

H1:Disclosure of economic dimension has effect on company's financial performance.

The environmental dimension is an important factor to show the existence and participation of businesses in dealing with environmental problems as a form of corporate responsibility towards the environment in which the company operates. Such disclosures are carried out to obtain certainty that the company has operated in accordance with applicable rules and norms. The company Journal of Wetlands Environmental Management Vol 7, No 1 (2019) 67 - 75 http://dx.doi.org/10.20527/jwem.v7.v1.188 reveals the environmental dimension trying to ensure that the company's actions are involved in disclosing sustainability report in order to get approval from the public and ensure that the company's operations continue. If the company's operations continue, the company's profits will increase. Disclosure of environmental performance can have an effect on financial performance at annual returns compared with industry returns which will certainly affect the company's image through company values (Nofianto \& Agustina, 2014;Tarigan \& Samuel, 2014; Rosyid, 2015). Based on these explanations, the hypothesis used to support these arguments is as follows:

H2: Disclosure of environmental dimension has effect on company's financial performance.

The social dimension in the sustainability report is related to the impact of the company on the community around the company. The disclosure of the social dimension in sustainability report is expected to provide tangible information that the production activities carried out by the company are not only oriented towards profit but also concern the environmental and social, increasing stakeholder confidence (Rosyid, 2015 ). The company reveals the social dimension to attract investors and maintain the survival of the company for a long period of time and helps improve the company's image, attracts public sympathy so that people are more loyal and like the products produced by a company. From the description, the hypothesis to be used is as follows :

H 3: Disclosure of social dimension has effect on the company's financial performance 
MATERIALS AND METHODS

\section{Population and Samples}

The companies which become the samples in this study are the companies included in the ISRA (Indonesia Sustainability Reporting Award) nomination which are listed on the Indonesia Stock Exchange (IDX) in 2016-2017 not the financial sector. The samples that fit with the criteria are 20 companies with a total of 40 observations. The companies were chosen because they have a clear vision and mission and a sustainability business program and in general, the companies also show the openness to stakeholder involvement.

\section{Operational Definition and Variable} Measurement

\section{Independent Variables}

The proxy variable used is SRDI (Sustainability Report Disclosure Index) which is regulated in GRI-G4 Guideliness. In GRI-G4 Guideliness the disclosure of items is more than GRI-G4 Guideliness which is 91 items. Economic dimension consists of 9 disclosures, environmental dimension consists of 34 disclosures and social dimension consists of 48 disclosures. The measurement of the disclosure of each dimension is as follows (Wijayanti, 2016):

$$
\mathrm{SR}=\frac{\text { Total Items disclosed }}{\text { Maximum Score }} \times 100 \%
$$

\section{Dependent Variable}

The dependent variable (y) is a variable that can be influenced by independent variables. The dependent variable is used to examine the relationship between the independent variables and the dependent variable. The research uses profitability ratio as the dependent variable that is proxied by using ROA (Kasmir, 2014).

ROA Formula is: Net Profit / Total Assets

\section{Data Testing}

Data were analyzed using Multiple Linear Regression Analysis. Regression Analysis is used to determine the effect of sustainability reporting disclosures on the company's financial performance.

\section{RESULTS AND DISCUSSION}

\section{Descriptive Statistics}

Based on the results of descriptive testing describing the three dimensions of sustainability reporting.Disclosure of economic dimension ranging from $0 \%-88.90 \%$. Disclosure of environmental dimension from $11.80 \%-70.60 \%$ and disclosure of social dimension as much as $10.40 \%-81.30 \%$. While Return on Assets (ROA) shows a decrease of up to $55.83 \%$ with a maximum increase of $52.57 \%$. This indicates that the company's financial condition is not stable.

\section{Comparison of Sustainability Reporting Disclosures with Financial Performance in 2016 and 2017}

\footnotetext{
Sustainability Reporting describes a combination of disclosure of 3 dimensions, namely economic, environmental and social, while financial performance is measured using Return on Assets (ROA).
} 


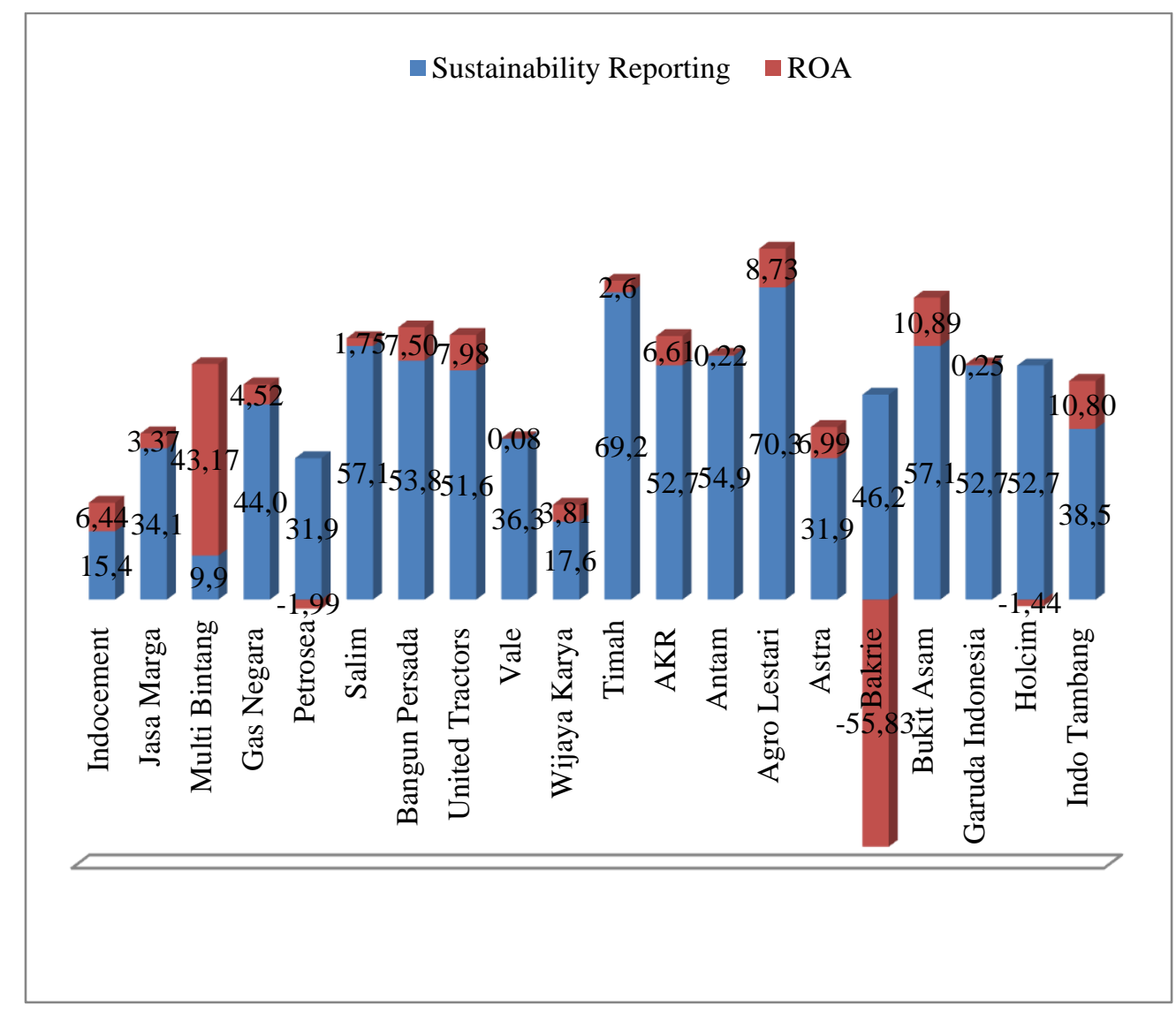

Fugur 1. Sustainability Reporting Disclosure and Financial Performance (ROA) Year 2016

\section{Sustainability Reporting Disclosures with Financial Performance in 2016}

Figure 1 clearly shows the relationship of sustainability reporting disclosure with the company's financial performance. The percentage of sustainability reporting disclosure varies from $9.9 \%$ to $70 \%$. The highest sustainability reporting disclosure was carried out by PT. Astra Agro Lestari, Tbk as much as $70 \%$, while PT. Multi Bintang Indonesia, Tbk, which posted the highest profit with ROA of $43.17 \%$. This condition indicates companies that report improved financial performance or report increased profits have the awareness to disclose more sustainability reports as a form of social responsibility to stakeholders.

\section{Sustainability Reporting Disclosures with Financial Performance in 2017}

Figure 2 clearly shows the sustainability reporting disclosure of 2017 varies from 11\% to $67 \%$.This year, many companies experienced fluctuating earnings changes compared to 2016, which affected the company's financial performance. There were several companies that experienced a decline in profits such as PT. Bakrie \& Brother, Tbk; PT. Garuda Indonesia, Tbk and PT. Holcim Indonesia, Tbk. However, the companies were still trying to report its sustainable activities. The highest sustainability reporting disclosure was carried out by PT. Indo Tambang Raya Megah, Tbk as much as $67 \%$ and PT. Multi Bintang Indonesia, Tbk, which posted a profit with the highest ROA of $52.67 \%$. 


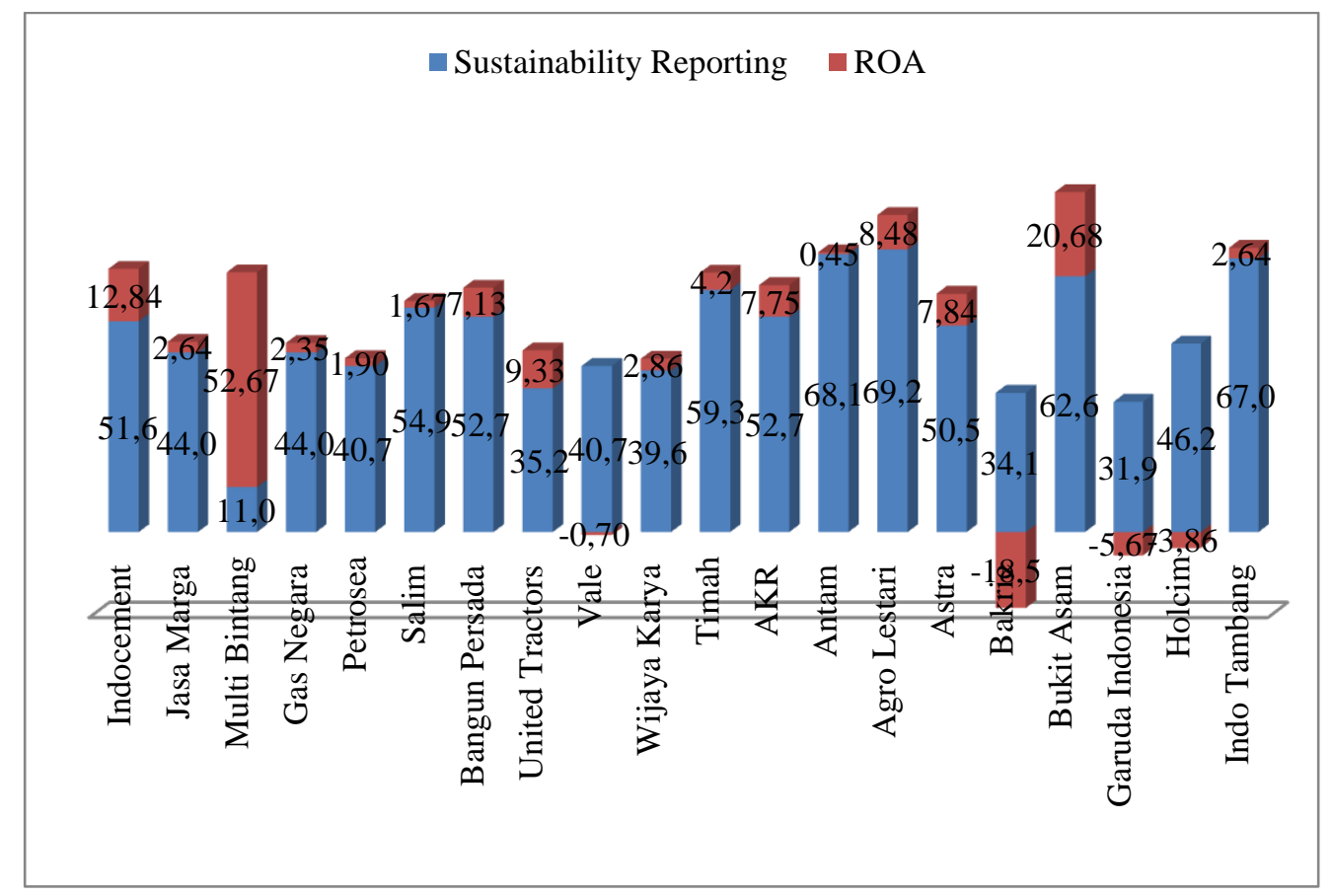

Figur 2. Sustainability Reporting and Financial Performance Year 2017

\section{Statistical Test}

Regression statistical test was used to determine the effect of economic dimension (H1), environmental dimension (H2), and sosial dimension on financial performance.

The economic dimension has effect on financial performance $(\mathrm{H} 1)$ so the hypothesis is accepted. The result of the test showed that financial performance provides information about the financial condition of a company in a certain period that the development can be seen in financial statements. The economic dimension in the sustainability report provides an explanation of organization impact related to economic conditions of stakeholders and economic system of companies at the local, national and world level (Natalia \& Tarigan, 2014). Information contained in economic performance is considered more transparent

Table 1 Results of Multiple Regression Analysis

\begin{tabular}{lrcrl}
\hline Variable & $\begin{array}{c}\text { Regression } \\
\text { Coefficient }\end{array}$ & t value & Sig. Explanation \\
\hline Economic & -.305 & -2.656 & .012 & Accepted \\
Environmental & -.025 & -.112 & .911 & Rejected \\
Social & .042 & .189 & .851 & Rejected \\
\hline Adjusted R Square $=0,136$ & F calculate $=3.051$ & \\
$\mathrm{n}=40$ & \multicolumn{5}{c}{ Sig. F $=0,041$} \\
\hline
\end{tabular}

Source: Data reprocessed (2018) 
when compared to the financial performance of the company, because stakeholders consider economic performance to be higher in accuracy for predicting and analyzing information at lower risk. With this information can increase confidence regarding competitive capital resources at the minimum risk level for stakeholders. From the result of regression coefficient testing the economic dimension has a negative direction, it can be explained that the companies have a quite high desire to disclose economic dimension with an average disclosure of $60.57 \%$. Like PT. Backrie\& Brothers, Tbk in 2016 experienced a decline in profit with ROA of $-55.83 \%$, but the disclosure of the economic dimensions carried out in sustainability reporting reached $88.90 \%$. Similarly, PT. Antam, Tbk in 2017 posted a profit that was not too high with ROA of $0.45 \%$ but revealed an economic dimension disclosure of $88.90 \%$. The conditions above are in line with the legitimacy theory even though the company's financial performance does not show good condition reflected by ROA, but encourages companies to ensure that their activities and performance are acceptable to the community.

The environmental dimension has no effect on financial performance (H2) so the hypothesis is rejected. Environmental performance has no effect on financial performance because sustainability report affects the value of the company and market response in a long time. (Adams, at al, 2010; Burhan \& Rahmawati, 2012, Nofianto \& Agustina (2014). The average score of environmental performance disclosure and ROA of each company are still fluctuating within 2 years started in 2016-2017. ROA condition, showed an average yield of $4.58 \%$ with fairly sharp financial performance fluctuations. The company that most disclosed its environmental dimension was PT Timah, Journal of Wetlands Environmental Management

Vol 7, No 1 (2019) 67 - 75

http://dx.doi.org/10.20527/jwem.v7.v1.188
Tbk as many as $70.6 \%$ of disclosures in 2016 , the company that most disclosed their environmental dimension was PT Antam, Tbk as much as $70.6 \%$.

The social dimension has no effect on financial performance (H3) so the hypothesis is rejected. The implementation of the social dimension requires a large asset investment in implementing sustainability activities. Sustainability activities are carried out not only for external stakeholders, but also internally. Stakeholders in Indonesia have not all seen the elements reported in the sustainability report as consideration in making decisions so that the sustainability report's impact on financial performance has not been seen (Adams et al, 2010; Nofianto \& Agustina, 2014). The social dimension in the sustainability report disclosed an average of $45.58 \%$. PT. Indo Tambang Raya Megah, Tbk experienced a rise in company profit in 2016 with ROA of $10.80 \%$, but only disclosed the social dimension in its sustainability reporting based on GRI-G4 was only 33.3\%. In 2017 PT. Bukit Asam (Persero), Tbk with ROA level of $20.68 \%$ with social dimension disclosure rate of $70.8 \%$.

The limitation of the research is the sustainability activities are not all referring to GRI-G4, but based on the activities that are in accordance with the activities carried out by the companies so far which become specifications of the company so that the percentage of disclosures based on these indicators is still low. This research can only explain the financial performance variable of $13.6 \%$, while the remaining $86.4 \%$ is explained by other variables outside the research. The suggestions given based on the results of regression coefficient statistical tests showed that only $13.6 \%$ of the sustainability reporting dimension can affect the company's financial performance, so it is necessary to look for other measures in sustainability reporting disclosure. In addition, 
it is necessary to expand the observation period so that the long term impact can be seen and the research samples are not limited to the companies included in the ISRA nomination.

\section{CONCLUSIONS}

Sustainability report is a practice of measurement, disclosure and accountability efforts of organizational performance in achieving sustainable development goals for both internal and external stakeholders that illustrate the coverage of economic, social and environmental activities. It can be concluded that the economic dimension disclosure has effect on financial performance because the information contained in economic performance is considered more transparent when compared to the financial performance of the company, because stakeholders consider economic performance to be higher in accuracy for predicting and analyzing information at lower risk, whereas the environmental and social dimensions have no effects. Sustainability report can affect the value of the company and can be felt in the long term, especially the environmental dimension. This condition is caused by the Stakeholders that have not all seen the elements reported in the sustainability report as consideration in making decisions. The impact of sustainability report on financial performance cannot be seen.

\section{REFERENCES}

Anthony, A. A., Robert, S. K., \& Ella, M. M. (2012).Akuntansi Manajemen, Edisi Kelima, Jilid 2. Jakarta Barat: PT. Indeks Permata Puri Media.

Adams, M., Thornton, B., \& Sepehri, M. (2010).The Impact of the Persuit of Sustainability on the Financial Performance of the Firm. Journal of Sustainabilty and Green Bussiness.JacsonvilleUniversity.

Burhan, A. H., \&Rahmawati, W. (2012).The Impact of Sustainability Reporting on Company Performance.Journal of Economics, Business and Accountancy. Ventura volume 15 No 2 , 257-272.

Deegan, C. (2006). Financial Accounting Theory (2nd ed). Sydney: McGraw-Hill Book Company.

Dewi, K. E., \&Sudana, I. P. (2015). Sustainability Reporting danProfitabilitas (StudiPadaPemenang Indonesia Sustainability Reporting Awards).

Donaldson, T., \& Preston, L. E. (1995). The Stakeholder Theory of The Corporation: Concept, Evidence, and Implications. Academy of Management ReviewVol.24 No.2, pp.65-91.

Dowling, J., \&Pfeffer, J. (1975). Organizational Legitimacy : Social Values and Organizational Behavior. Pasific Sociological Journal Review, Vol.18, 122136.

Elkington. (1997). Cannibals with Forks: The Triaple Bottom Line of 21st Century business. GabriolaIsland ,BC:New Society Publishers .

Freeman, R. E \&McVea, J.2001. A Stakeholder Approach to Strategic Management. WorkingPaper No. 01-02

Hill,C. W., \& Jones, T. M. (1992). Stakeholder-Agency Theory.Journal ofManagement Studies 29:2 March, 0022238. 
Hanafi, M. M. (2013). ManajemenKeuangan. Yogyakarta: BPFE-Yogyakarta.

Kasmir. 2014. Analisis Laporan Keuangan, Edisi Pertama, Cetakan Ketujuh. Jakarta: Rajawali Pers. ISSN 978-979-769-216-2.

Ken, A. M \& Helmy, A. 2012. Faktor-Faktor yang Mempengaruhi Pengungkapan Sustainability Performance.Universitas Brawijaya. Malang.

Luthan E. (2010). Keterkaitan Antara Corporate Social Responsibility (CSR) danGood Corporate Governance (GCG) Dalam Meningkatkan Kinerja Perusahaan. Bandung: Unpad Press.

Maria, Y. K. P. A. 2014. Pengaruh Ukuran Perusahaan, Profitabilitas, Tipe Industri Terhadap Pengungkapan Sukarela Pelaporan Berkelanjutan.

Natalia, R., \& Tarigan, J. (2014).Pengaruh Sustainability Reporting Terhadap Kinerja Keuangan Perusahaan Publik dari Sisi Profitability Ratio.

Nofianto, E., \&Agustina, L. (2014).Analisis Pengaruh Sustainability Report Terhadap Kinerja Keuangan Perusahaan. Accounting Analysis Journal vol 3 No 3 .

Nur Maharani, S. (2014). Sustainability Reporting Sebagai Media Perusahaan dalam Mengembangkan dan Melaporkan
Kebijakan Bisnis Berkelanjutan. Jurnal Moderanisasi, Vol. 10. No. 1.

Rosyid, A. (2015). Pengaruh Kinerja Sosial dan Kinerja Lingkungan Terhadap Kinerja Keuangan.JurnalPenelitianVol 12 No. 1 , 72-85.

Safitri, D. A., \& Fidiana. (2015). Sustainability Report terhadap Kinerja Keuangan dan Pasar. Jurnal Ilmu \& Riset Akuntansi Vol. 4 No. 4 .

Slaper T. F., \&Hall. (2011). The Triple Bottom Line: What Is It and How Does It Work? Indiana Business Review.

Susanto, Y. K., \& Tarigan, J. (2013). PengaruhPengungkapan Sustainability Report Terhadap Profitabilitas Perusahaan. Business Accounting Review,Vol. 1.

Sustainability Reporting Award.SRA.NCSRID.ORG. diakses 15 September 2018.http://sra.ncsr-id.org/sra-participant/.

Tarigan,J.,\& Samuel, H. (2014). Pengungkapan Sustainability Report dan Kinerja Keuangan.Jurnal Akuntansi dan Keuangan,Vol. 16, No. 2,November 2014.

Wijayanti, R. 2016. Pengaruh Pengungkapan Sustainability Report terhadap KinerjaKeuangan Perusahaan. Universitas Muhammadiyah. Surakarta. ISSN 24600784. 